\title{
A proposta de um novo olhar
}

DOI: 10.1590/1809-58442016214

\section{Camila Escudero}

(Universidade Federal do Rio de Janeiro, Escola de Comunicação, Programa de Pós-Graduação em Comunicação e Cultura. Rio de Janeiro - RJ, Brasil)

D’AMARAL, Marcio Tavares. Os assassinos do sol uma história dos paradigmas filosóficos. Rio de Janeiro: UFRJ, 2015, 236p.

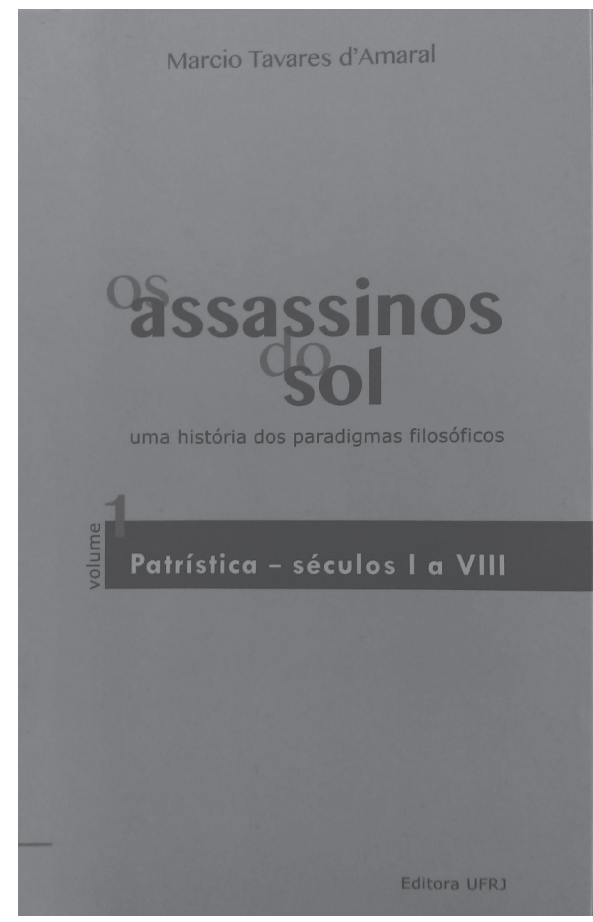

Um curso em formato de livro. Assim é a nova obra de Marcio Tavares d'Amaral, Os assassinos do sol. Trata-se do registro escrito das concorridas aulas que o renomado professor vem ministrando, desde 2002, nos cursos de mestrado e doutorado da Escola de Comunicação da UFRJ - programa, aliás, do qual é um dos fundadores (ao lado de Muniz Sodré e Emmanuel Carneiro Leão). Quem teve a feliz oportunidade de realizar algum período do curso, certamente, vai se deliciar com todo material estudado em classe reunido e acessível; quem não teve, poderá sentir o sabor das deliciosas, inteligentes e estimulantes discussões propostas.

O livro é um projeto ousado. Na verdade, é apenas o primeiro volume, de um total de oito, que d'Amaral pretende lançar nos próximos anos. Nele, está a história da Filosofia; mas não uma história qualquer, contada a partir de uma temporalidade causal e linear dos fatos, por exemplo, como estamos acostumados. São histórias de sistemas, de conjuntos de regras e valores - portanto, de poder - a partir de pensamentos e ideias que dão sentido ao mundo, ou seja, a história dos paradigmas filosóficos. Surpreendente? Espere então até saber que esta narrativa é construída, segundo o professor, em um momento da História em que se diz que a História acabou...

Os assassinos do sol começa quatro ou seis séculos depois do começo que habitualmente é assinalado uma história da Filosofia. Não o século VI dos pré-socráticos, nem o IV dos clássicos, mas o I, quando se localiza temporalmente a hipótese de Marcio 
Tavares d’Amaral: o encontro absolutamente improvável, em tese, da Filosofia grega (marcada pela racionalidade) com a tradição judaica (que tem na fé sua maior característica). Assim, o livro discorre sobre a formação da Patrística oriental grega: a Gnose Oriental, os antignósticos Irineu e Hipólito, os apologetas ocidentais (em especial Tertuliano), Clemente de Alexandria e Orígenes, Basílio, o Grande, Gregório de Nazianzo e Gregório de Nissa e, finalmente, o bispo de Hipona Agostinho de Tagaste, ou, o mais conhecido Santo Agostinho e sua obra A Cidade de Deus. Como se vê, tradicionais autores, obras e escolas foram mencionados e estudados, entretanto, a partir de sua contribuição para a constituição e surgimento de ideias demarcadoras do pensamento ocidental. E vale lembrar: esse é apenas o primeiro volume.

Com uma conexão aos nossos dias, o autor utiliza como recurso, durante todo o texto, o que ele chama de “algumas interrupções”, para realocar o tempo na sua narrativa. "Porque, a todo momento, será preciso chamar a atenção para o fato de que essa história se conta porque nós estamos atravessando uma mudança de mentalidades” (p.69). Apenas como exemplo, a “primeira interrupção” diz respeito a estarmos hoje passando pelo “advento da tecnologia” - essa fusão do saber com o saber fazer que, durante 24 séculos, foi impossível e, aliás, nunca reivindicada.

Simplesmente não esteve, por esse tempo, no horizonte do sentido. De fato, era impossível que essa fusão ocorresse muito antes porque o saber saber - a episteme - era o lugar da verdade, e a verdade questão cognata à do ser. A necessidade, que talvez hoje esteja em cena, de reunir num só corpo tenso o saber e o fazer, a verdade e o que, não sendo falso, é, no entanto, de outra ordem de realização, não encontraria sequer um caminho, digamos linguístico para uma enunciação grega. (...) E, ao mesmo tempo a contração tecnológica que hoje experimentamos provavelmente não faria sentido, não despertaria atenção e espanto, não comoveria o pensamento se os antigos gregos não tivessem formulado a questão do Ser (D’AMARAL, 2015, p.70).

Ao retratar esse início de história dos paradigmas filosóficos, d’Amaral não registra apenas sua original perspectiva da Filosofia, mas inova também no formato do livro e em seu estilo discursivo. Não há capítulos e as partes são chamadas de “Aulas ministradas”, inclusive com a datação. Além disso, o fato de o autor ter optado por um texto corrido, sem as interrupções de um aparato de notas e referências - tradicionais em obras acadêmicas garante uma leitura agradável e prazerosa. "Foi assim que a conversa se passou nas aulas, e assim ficou quando as aulas passaram para o papel” (p.219), explica o professor. No final, entretanto, há alguns comentários e referências que ajudam aqueles que não têm tanta familiaridade com temas filosóficos.

Não poderíamos deixar de mencionar a “Abertura” do livro, que inicia com uma referência à morte de Beda, o Venerável, em 735 d.C. Aliás, aí pode estar uma pista para 
decifrar quem são os assassinos do sol, que o título do livro, enigmaticamente, propõe (e que, obviamente, não vamos contar para não estragar a surpresa). Na verdade, a "Abertura” é uma apresentação do que pretende todos os volumes, que ainda serão lançados. Se o primeiro dessa série trata da constituição de uma outra cultura cristã a partir do cruzamento inesperado, paradoxal e confuso das culturas grega e judaica, o segundo promete reconhecer os fundamentos dessa fusão e rever os filósofos gregos. O terceiro promete avançar para a Escolástica medieval, quando a questão nodal da fé e da razão ganha máxima visibilidade. A partir de então, os volumes 4, 5, 6, 7 e 8 devem discorrer, respectivamente, sobre o Renascimento e os modernos; Kant; Hegel, Kierkegaard e Schopenhauer; e Nietzsche. Tomara que não demorem a chegar.

Por fim, ao falar de Filosofia, Márcio Tavares d’Amaral pensa a História, a Política (principalmente as relações de poderes), a Linguística (a partir de explicações etimológicas e exemplos discursivos), a Teologia, a Sociologia e, por que não, a Comunicação. Se a obra é interdisciplinar - característica mais que enfatizada em nosso campo - a Comunicação, assim como a Filosofia, é essencial às relações humanas em qualquer área do saber.

\section{Camila Escudero}

Doutoranda em Comunicação e Cultura pela Universidade Federal do Rio de Janeiro (UFRJ). Atualmente, desenvolve pesquisa no Latin American and Latin Studies Program da Universidade de Illinois, em Chicago (UIC), com bolsa de Doutorado Sanduíche da Fundação de Amparo à Pesquisa do Estado do Rio de Janeiro (FAPERJ). E-mail: camilaescudero@uol.com.br 